\title{
Transformational Leadership and Job Performance of SMEs Technical Personnel: The Adaptability Cultural Approach as Mediator
}

\author{
Arman Hadi Abdul Manaf \\ Open University Malaysia \\ Email: arman_hadi@oum.edu.my \\ Latifah Abdul Latif \\ Universiti Sains Malaysia
}

\section{Doi:10.5901/mjss.2014.v5n20p648}

\section{Abstract}

The relationships between transformational leadership style, adaptability cultural trait and job performance were examined in this study. Hierarchical multiple regression analysis was computed to test adaptability trait as a mediator on variables selected. It has resulted that adaptability cultural trait mediates between the leadership style and employees' job performance in the SMEs. The adaptability cultural trait practiced in an organization through leadership is significant in re-designing and restrategizing on possible manner to deliver tangible and sustainable results in the future due to fast changing business landscape. This study contributes to the dynamics of the causative relations between examined variables and highlights the significance of transformational leadership, organizational culture in ascertaining job performance in the context of Malaysian SMEs.

Keywords: transformational leadership style; adaptability cultural approach; job performance; SMEs

\section{Introduction}

The South East Asia countries acknowledged on the effectiveness in organizational leaders toward succession to organizations, this includes Malaysia as one of a developing country in the region. According to Kessels and Keursten (2002), businesses are experiencing tough challenges which threaten the stability of the organization due to changes in business landscape and technological advancements. Any organizations need to identify, prioritize and strategically to overcome these arising challenges in order to become competent and stay relevant in the industries they are with.

In this regard, the Small and Medium Size Enterprises (SMEs) play a significant part to a country's economy development and provide approximately $45 \%$ of the employment and contribute about $40 \%$ of national profits (Department of Statistics, 2005). As mentioned by Saleh, Caputi and Harvie (2008) and SMIDEC (2005) that a comprehensive survey by National SME Development Council was conducted in 2005 involving over 500,000 business organizations in Malaysia and $99.2 \%$ are SMEs; therefore they are significant to the Malaysian economic succession. SMEs functioned as central element to the economic activity linking the small enterprises with established corporations. Small firms supply various products and provide services to one another as well as to larger firms. For example, Sears America purchases merchandise from approximately 12,000 suppliers and most of them are small enterprises.

In addition, the new market entrants and business pressures have resulted in increased challenges of survival to small businesses due to their business size and scarce resources. These challenges are not only originating from their peers but also by large industries and the reliance on domestic markets for business growth performance is an issue of the past for many SMEs. The Central Bank of Malaysia has reported that the Malaysian SMEs are partly contributing to the Malaysian economic development.

In this relation, performance is the ability of an organization to fulfil the demands of the investors by assessing the company's achievements (Smith and Reece, 1999). Business investors are pressuring on organizations to strategically manage on value assets with the organization's business goals. One of the major concerns for organizations in Malaysia especially the SMEs need to reformulate a strategy to enhance performance and to re-engineer their business modules.

In today's globalization scenario, intensity in competition, progression in product life-cycle, and the expansion in complexity of associations with suppliers, customers, employees, and government (Kotabe and Murray, 2004; Knight and 
Cavusgil, 2004), organizations have realized that leadership in change management has become an important aspect of running businesses for future survival. Leadership is a crucial factor in engineering improvement on corporate behaviours and the ability (i) to motivate, (ii) to guide others in realizing the vision, objectives, mission, (iii) to be creative, innovative and promote new ideas for organizational growth and (iv) adaptable to changes; as well as to acquire the dynamics of culture to empower and engage members, build teamwork and enhance capabilities.

Importantly, the success of any types of organizations is depending on the connectedness between leaders and followers (Chu, Yang and Chen, 2011; Lau and Tong, 2008). In attempt to accommodate the new technologies and environmental challenges, cultures practiced in organizations and leadership is constantly undergoing the process of change. In other words, in Malaysia especially in the Northern region, the field of adaptability cultural approach and transformational leadership style has been lacking in the job performance determinants. Most of the SME business owners are unaware of their practiced leadership style as well as the cultural work approach embedded among their personnel.

Transformational leadership has become as the most important benchmark in organizations (Sarros and Santora, 2001; Levy, Cober and Miller, 2002). A transformational leader is an individual with charisma who is able to make subordinates feel passionate about the success of an organization. The benefits of transformational leadership are seen in nearly every aspect of operations in organizations. Therefore, there is a necessity to assess the style in leadership of the business owners as well as the work culture practiced as perceived by the employees on the level of job performance.

This study aims to determine the direction and strength of the relationships between perceptions on transformational leadership, adaptability culture trait practiced toward betterment in the SMEs task performance due to changes in the economic landscape.

\section{Literature Review}

\subsection{Defining styles of leadership}

Leadership is a key factor in an organization's performance and achievement indicator. The study of leadership is an active field of inquiry because it has been practiced for a long time and there is a large body of academia pertaining to it (Goleman, Boyatzis and McKee, 2002); Kouzes and Posner (2002); Abbas and Yaqoob (2009) and Yukl and Lepsinger (2005) mentioned studies on leadership continue to expand as the number of new theories and models continue to be introduced.

A prevalent recurrence in the study of leadership was the study of leadership styles (Moore and Rudd, 2006, p.6). Casimir (2001) defined styles in leadership as a pattern of emphasis, indexed by the frequency or intensity of specific behaviours or attitudes which a leader demonstrates based on his or her various functions. Research suggests that various leadership styles were applied in different situations (Turner and Muller, 2005; Muller and Turner, 2007). There is no exact style in leadership which is ideal for all situations, since a leader may have limited knowledge and skills to react effectively in a situation but may not emerge as effectively in the other as stressed by Rad and Yarmohammadian (2006).

Various styles are needed in different organizational conditions and leaders need to know the best time to demonstrate the best approach, and how to express their abilities to influence others in respond to shared organizational goals (Armandi, Oppedisano and Sherman, 2003). This is important for leaders to adjust accordingly in order to fit into the changes in the organizational settings and manage the task force.

\subsubsection{Transformational leadership style}

According to Bass (1985a; 2000), transformational leaders modify culture in organization by positioning its culture with learned visions and defined transformational administration in terms of leader's motivational effect on followers' loyalty, trust, admiration and respect to the leaders. There were many scholarly published works in analyzing the inter-connection between organizational culture and culture management, and is much often associated with organizational change (Schein, 1990; 1996).

This is due to a set of organizations which attempt to administer with the ever-increasing complexities of their environment in respect of changing their culture in organization. In this particular instance, transformational leadership is required for complex and culturally diverse organizations as argued by Cascio (1995 in Ellemers, De Gilder and Haslam, 2004).

Further, Avolio, Bass and Jung (1999) argued that transformational leadership constitutes for effective leadership, 
and together they take effect on organizational culture. Moreover, Schein (1992 cited in Buch and Wetzel, 2001) argued, organizational culture is revealed in norms, shared values, and basic assumptions. In this relation, other researchers have identified components of organizational culture as well.

\subsection{Culture in organization}

Van Den Berg and Wilderom (2004, p. 578) highlighted, two important distinctions between leadership and culture: (i) leadership denotes behaviour displayed by one or only few individuals, while culture is a collective behavioural phenomenon and (ii) leadership involves a potentially one-sided dependency relations. House, Javidan, Hanges and Dorfman (2002) and Javidan, House, Dorfman, hanges and De Luque (2006) stated that leadership directly affects on organizational form, culture, and practices. Organizational culture refers to a shared system held by employees.

Examples of organizational culture are items such as behaviour, language, values, symbols and rituals (Ott and Sullivan, 1989 cited in Mehra et al., 2006; Davies, Nutley and Mannion, 2000). It is a composite structure of norms that emphasises the administering of individuals (Lytle, Brett, Barsness, Tinsley and Janssens, 1995 and Johnson, 1992). Culture refers to the outcomes due to the routine interactions and negotiations among members of a particular organization through mutual agreement on the righteous procedure to perform tasks. Sadri and Lees (2001) stated that culture in organization is governed by several factors namely the background of industry, respective location, previous occurrences, members' behaviours and interaction styles.

\subsubsection{Adaptability cultural trait approach}

Adaptability measures an organization's ability to adapt swiftly to abrupt changes in the business condition such as demanding needs of customer and the market environment. Schein (1992) explained that culture is able to change and to adapt into new environmental conditions. It means that an organization able to perform in a competitive environment as compared to only being able to perform in a safe and stable environment (Gordon and DiTomaso, 1992).

Further exploring the term adaptability, Calori and Samin, (1991) and Cameron, Freeman and Mishra (1991) asserted that adaptability was not about profit but about long term growth. Becoming adaptive or non-adaptive can be applied in the element of culture. For adaptive cultures, leaders focused more on corporate customers and those internally involved (employees), the processes and procedures that demonstrate on significant change. Adaptable organizations translate the demands of the organizational environment into action. They take risks, and learn from their mistakes, and have capability and experience at creating change (Kotter, 1996).

Any organizations that exhibit high adaptability level are stimulated by customer needs, willingness to take risks, and learn through mistakes (Nadler and Nadler, 1998 in Fernandez and Rainey, 2006). Contradicting to this, organizations in non-adaptive cultures are more concerned with their own agendas, and their values tend to be lacking in risk-taking and process of change. Possessing strong culture is insufficient; a well adaptive culture is highly essential to encourage the organization in its progress toward the desired organization future direction in order to create change, focus more on customer needs, and enhance organizational learning (Daft, 2005).

\subsection{Job performance}

Job performance is the engagement of employees' behaviour at their workplace. According to Visweswaran and Ones (2000), the individual work performance has been significantly important in various employment relations research. Organizations acquire highly performing human capital in order to achieve their business objectives, to distribute their specialized products and services as well as to accomplish competitory benefits.

Performance is also important to individual. Accomplishing tasks and performing at a high level can be a source of satisfaction, with feelings of mastery and pride. The most significant factor which matter in the business industry and organization psychology is job performance. In this support, Borman (2004) and Kiker and Motowildo (1999) stated that other than employee training and job redesigning, the continually focus is on job performance and organizational effectiveness.

Job performance has been categorized into two elements namely: task performance and contextual performance. Task performance is referred to configurations of behaviours that implicate production of goods or services or any processes that afford circuitous aid for company's innermost technical series of actions (Kahya, 2007). Further, contextual performance is related to efforts undertaken by individuals that are not related to his or her main job function, however it is significant due to it design the organization, social and psychological context that render as a catalyst for 
operational activities and processes (Werner, 2000; Werner and DeSimone, 2009).

\section{Methodology}

\subsection{Research framework}

A theoretical framework refers to a conceptual model of how one theorizes the links between several factors which have been identified as elementally critical to the problem (Sekaran and Bougie, 2010). Published research indicates that it plays an important role in the development of a scientific tool to investigate the research problems which incorporate one's logical beliefs (Sekaran, 2000). The theoretical framework shows the interrelatedness among the variables, the extent that the variables are deemed to be integral in the dynamics of the situation which are being investigated such as in this current study. By developing the theoretical framework as shown in Figure 1 in order to identify the determinant factor, it serves as a guide as the research questions are fine-tuned, measurement methods are selected and statistical analyses are determined.

\section{Figure 1}

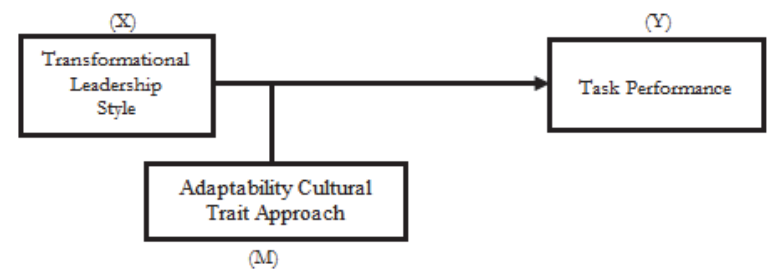

According to MacKinnon, Lockwood, Hoffman, West and Sheets (2002) psychologists refers this condition as $X \rightarrow M \rightarrow$ $Y$ relationship known as "mediation" or "indirect effect" of $X$ on $Y$ through M.Figure 1 indicates that there is a direct effect relating $X$ to $Y$ and a mediated effect by which $X$ indirectly affects $Y$ through $M$. Several SMEs involved in the manufacturing industry were selected in this study. Therefore, the outcomes of employees' perceptions on their immediate superiors' style in leadership and adaptable cultural trait practiced in the organization were investigated.

The hypotheses are as follows:

Ho1 Transformational leadership style is not significantly associated with the job performance

Ha1Transformational leadership style is significantly associated with the job performance.

Ho2Transformational leadership style is not significantly associated with adaptability cultural trait approach.

Ha2Transformational leadership style is significantly associated with adaptability cultural trait approach.

Ho3Adaptability cultural trait has no significant influence in determining the job performance outcome.

Ha3Adaptability cultural trait has significant influence in determining the job performance outcome.

Ho4Adaptability cultural trait does not function as a mediator in the relationship between transformational leadership style and job performance outcome.

Ho4Adaptability cultural trait does function as a mediator in the relationship between transformational leadership styles and job performance outcome.

\subsection{Research design}

Research design is a roadmap of research formed to conform on research questions as possibly valid, reliable and prudent (Creswell, 2003; 2005). The quantitative methods are research methods which utilize statistical data to make sense of the world (Bryman and Bell, 2007). A survey research method was chosen in this study due to its practicality for descriptive, explanatory and exploratory research and thus it was applied in order to fit into the objective of this research study. The survey method can be used, and is considered paramount in measuring attitude and to gain personal and social information including their beliefs (Rossi and Freeman, 1993; Bryman and Bell, 2011). It furnishes an accurate personification or account of the characteristics such as behaviour, opinions, abilities, beliefs, and cognition of an individual, situation or group. 


\subsection{Collection of data}

A survey questionnaire was applied as data collection instrument due to its ability to study a large sample randomly. A questionnaire is a printed self-report form designed to elicit information that can be obtained through the written responses of the subjects. The questionnaires were administered among technical personnel in the selected manufacturing SMEs in the Northern region of Malaysia. The survey produced $78.79 \%$ of response rate indicating an amount of 131 usable responses.

\subsection{Instrumentations}

The variables are anchored by a five-point Likert scale ( 1 - strongly disagree to 5 - strongly agree) and measured through the application on the existing instruments and which have already been tested and validated from previous studies. Transformational leadership style variables are adapted from Bass and Avolio (1997), known as Multifactor Leadership Questionnaire (MLQ) 5X. The Denison and Mishra (1995) model for culture adaptability trait as well as Job Performance by Coleman and Borman (2000) were chosen. The data were analyzed using the Statistical Package for the Social Sciences (SPSS Version 20.0 for Windows).

\subsection{Sampling and respondents}

The sampling chosen to be examined covers on the selected SMEs in the North peninsular of Malaysia. The respondents $(n=131)$ of this study are the technical personnel in the production department who held a minimum of a Diploma qualification.

\section{Data Analysis}

The findings were obtained from the selected SMEs in the manufacturing business. The information gathered was based on the survey questionnaires which have been distributed to employees who are holding a technical position. The questionnaire used in this survey is based on the employees' perception on their immediate superiors' acceptance toward the need of change in the operational processes as well as the organization as a whole.

\subsection{Reliability analysis}

The Cronbach alpha is applied in the study in was to assess the reliability of the constructs in order to indicate the sufficiency the items complementing to one another (Sekaran, 2000; Sekaran and Bougie, 2010). According to Nunnally (1978) and Field (2005), a value of 0.7 above is an acceptable value of Cronbach's Alpha and considered as reliable. Therefore, Table 1 illustrates the reliability of the current tests on the variables.

\section{Table 1}

\begin{tabular}{|l|c|c|}
\hline Variables & Main Test (a) N=131 & No. of Items \\
\hline -Idealized Influence (Attribute) & 0.703 & 4 \\
-Idealized Influence (Behaviour) & 0.701 & 4 \\
-Inspirational Motivation & 0.713 & 4 \\
-Intellectual Stimulation & 0.710 & 4 \\
-Individual Consideration & 0.701 & 4 \\
-Adaptability Cultural Trait & 0.889 & 15 \\
-Task Performance & 0.723 & 6 \\
\hline
\end{tabular}

\subsection{Factor analysis}

The five (5) dimensions constituting of transformational leadership style, adaptability cultural trait as well as job performance were measured. The suitability of data was assessed through factorial analysis. The correlational matrix has shown that the existence of many coefficients with the value of more than 0.5 and the items are remained. The KMO value for (i) Transformational leadership style is 0.828 ; (ii) Adaptability cultural trait is 0.886 , and (iii) Job performance is 
0.724. The results from the applied instrumentations in the study have satisfied the requirement of Kaiser-Meyer-Olkin $(K M O)$ test. Validity is claimed when the value of variables are more than $0.05(p>0.05)$ as stated by Field $(2005)$.

\subsection{Hierarchical multiple regression analysis}

A four-step hierarchical multiple regression analysis (MacKinnon, Lockwood, Hoffman, West and Sheets, 2002) was applied to determine whether the selected variable (Adaptability cultural trait) mediates the relationship between transformational leadership style and the employees' task performance in the work environment. Figure 2 represents the results of the mediation analysis by multiple regressions to determine that adaptability cultural trait approach as a mediator to strengthen the relationship between Transformational leadership style and technical staff members' job performance.

Figure 2: The mediation analysis

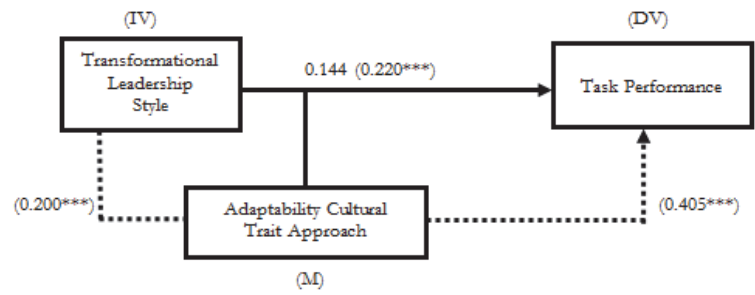

In reference to Figure 2 above, where $\beta a=0.200$ (the standardized beta coefficient of the IV $\rightarrow M$ (with all controls in the equation); $\beta b=0.405$ (the standardized beta of the M $\rightarrow$ DV (with IV and controls in the equation); $\beta c=0.144$ (the coefficient of the IV when the mediator and controls are in the equation); and $\beta c^{\prime}=0.220$ (the coefficient for the IV when the controls are in the equation but the mediator has not been entered).

The coefficient is marked as * to indicate $p<.05$, ${ }^{*}$ for $p<.01$, and ${ }^{\star * *}$ for $p<0.001$. The result indicates that $X$ remains significant (whereby both $X$ and $M$ are both significantly predict $Y$ ), and the finding support partial mediation $(p=$ 0.003). The hypothesis null four ( $\mathrm{Ho4}$ ) is rejected and hypothesis four ( $\mathrm{Ha} 4)$ is supported.

The hypotheses tested have proven that adaptability cultural trait functions as a mediator in bridging leadership style and SMEs technical staffs' job performance in their workplace environment. This has been indicated through the smaller value of the statistical results after the inclusion of adaptability cultural trait approach on the effect of leadership and performance outcome.

\section{Conclusion}

This study expects to uncover the link between leadership-culture and how it affects SME employees' performance at the workplace in becoming competitive in the current aggressive and demanding business environment. Organizational culture shapes organizational member experience which lead to their behavior, and understanding the cultural boundaries of leadership due to a business world has become. Past studies have examined on the relationship between leadership and performance (e.g. Howell and Avolio, 1993); culture and performance (e.g. Denison, 1990a cited in Jaskyte and Dressler, 2004); leadership and organizational culture (e.g. Schein, 1992) the association of the three components such as Parry and Proctor-Thomson (2003); Xenikou and Simosi (2006).

However, unlike previous studies which focuses on a direct link analysis, this study has intended to examine on the causal effect with the inclusion of adaptable cultural trait as a mediator. The interpretation of this finding does not to conclude that leadership styles are irrelevant in relation to employees' performance but relatively to prove that cultural practices do emerged as a filtering mechanism and resulting as main predictor to the organization members' performance outcomes instead of analysis between leadership styles and performance.

Organizational culture is important to establish an organization (Martins and Terblanche, 2003). The uniqueness of culture in the organizational system, structures and policies are regulated by the leaders. It is within these policies and organization structures that shape organizational behaviors as a whole. It is imperative that leaders and managers to be advocated on the importance of culture have on the organization's operational activities. Leaders need to discover the kinds of culture that are favorable to an organization's growth and focus on strengthening positive work culture. 


\section{References}

Armandi, B., Oppedisano, J. \& Sherman, H. (2003). Leadership Theory and Practice: A "Case" in Point. Management Decision, 21 (10), 1076-1088.

Avolio, B. J., Bass, B. M. \& Jung, D. I. (1999). Re-examining the Components of Transformational and Transactional Leadership using Multifactor Leadership Questionnaire. Journal of Occupational and Organizational Psychology, 72 (4), 441-462.

Bass, B. M. (1985a). Leadership and Performance Beyond Expectations. New York: Free Press.

Bass, B. M. (2000). The Future of Leadership in Learning Organizations. Journal of Leadership and Organizational Studies, 7 (3), $18-40$.

Bass, B. M. \&Avolio, B. J. (1997). Full Range Leadership Development: Manual for the Multifactor Leadership Questionnaire. Palo Alto, California: Mind Garden.

Borman, W. C. (2004). The Concept of Organizational Citizenship. Current Directions in Psychological Science, 13 (6), $238-241$.

Bryman, B. and Bell, E. (2007). Business Research Methods (2nd ed.). Oxford: Oxford University Press.

Bryman, B. and Bell, E. (2011). Business Research Methods (3rd ed.). Oxford: Oxford University Press.

Calori, R. \&Samin, P. (1991). Corporate Culture and Economic Performance: A French Study. Organization Studies, 12 (1), $49-74$.

Cameron, K. S., Freeman, S. J. \& Mishra, A. K. (1991). Best Practices in White-Collar Downsizing: Managing Contradictions. The Executive, 5 (3), 57-73.

Cascio, W. F. (1995) Whiter Industrial and Organizational Psychology in A Changing World of Work?. In Ellemers, N., De Gilder, D. \& Haslam, S. A. (2004). Motivating Individuals and Groups at Work: A Social Identity Perspective on Leadership and Group Performance. Academy of Management Review, 29 (3), 459-478.

Casimir, G. (2001). Combinative Aspects of Leadership Style: The Ordering and Temporal Spacing of Leadership Behaviors. The Leadership Quarterly, 12 (3), 245-278.

Chu, H. C., Yang, Y. F. \& Chen, C. Y. (2011).The Dyadic effect of Leadership and Conflict Management on Trust in the Context of Life Insurance Companies in Taiwan. African Journal of Business Management, 5(11), 4272-4285.

Coleman, V. I. \& Borman, W.C. (2000).Investigating the Underlying Structure of the Citizenship Performance Domain. Human Resource Management Review, 10 (1), 25-44.

Creswell, J. W. (2003). Research Design: Qualitative, Quantitative, and Mixed Methods Approaches (2nded.). Thousand Oaks, CA; Sage.

Creswell, J. W. (2005). Educational Research: Planning, Conducting, and Evaluating Quantitative and Qualitative Approaches to Research (2nd ed.). Upper Saddle River, New Jersey: Merrill/Pearson Education.

Daft, R. L. (2005). The Leadership Experience (3 $3^{\text {rd }}$ ed.).Mason, Ohio: Thomson, South-Western.

Davies, H. T. O., Nutley, S. M. \&Mannion, R. (2000).Organizational Culture and Quality Health Care. Quality in Health Care, 9, $111-119$.

Denison, D. R. \& Mishra, A. K. (1995). Toward a Theory of Organizational Culture and Effectiveness.Organization Science, 6 (2), $204-$ 227.

Denison, D. R. (1990a) Corporate Culture and Organizational Effectiveness. In Jaskyte, K. \& Dressler, W. W. (2004).Studying Culture as an Integral Aggregate Variable: Organizational Culture and Innovation in a Group of Nonprofit Organizations.Field Methods, 16 (3), 265-284.

Department of Statistics, Malaysia (2005). Census of Establishments and Enterprises (Preliminary Data).

Field, A. (2005). Repeated-Measures Design, Discovering Statistics Using SPSS (pp. 427-482). London: SAGE Production.

Goleman, D., Boyatzis, R. E. \& McKee, A. (2002). The New Leaders.Cambridge, MA: Harvard Business School Press.

Gordon, G. G. \&DiTomaso, N. (1992).Predicting Corporate Performance from Organizational Culture. Journal of Management Studies, 29 (6), 783-798.

House, R., Javidan, M., Hanges, P. J. \&Dorfman, P. (2002). Understanding Cultures and Implicit Leadership Theories Across the Globe: An Introduction to Project GLOBE. Journal of World Business, 37 (1), 3-10.

Howell, J. M. \&Avolio, B. J. (1993). Transformational Leadership, Transactional Leadership, Locus of Control, and Support for Innovation: Key Predictors of Consolidated-Business-Unit Performance. Journal of Applied Psychology, 78 (6), 891-902.

Javidan, M., House, R., Dorfman, P. W., Hanges, P. J. \& De Luque, M. S. (2006). Conceptualizing and Measuring Cultures and Their Consequences: A Comparative Review of GLOBE's and Hofstede's Approach. Journal of International Business Studies, 37 (6), 897-914.

Johnson, G. (1992). Managing Strategic Change - Strategy, Culture and Action. Long Range Planning, 25 (1), 28-36.

Kahya, E. (2007). The Effects of Job Characteristics and Working Condition on Job Performance. International Journal of Industrial Ergonomics, 37, Issue 2007, 515-523.

Kessels, J. \&Keursten, P. (2002). Creating a Knowledge Productive Work Environment. Lifelong Learning in Europe, 7 (2), $104-112$.

Kiker, D. S. \& Motowildo, S. J. (1999). Main and Interaction Effects of Task and Contextual Performance on Supervisory Reward Decision. Journal of Applied Psychology, 84 (4), 602-609.

Knight, G. A. \&Cavusgil, S. T. (2004).Innovation, Organizational Capabilities and the Born-Global Firm. Journal of International Business Studies, 35, 124-141.

Kotabe, M. \& Murray, J. Y. (2004).Global Sourcing Strategy and Sustainable Competitive Advantage. Industrial Marketing Management, $33(1), 7-14$.

Kotter, J. (1996). Leading Change. Harvard Business School Press, Boston.

Kouzes, J. M. \& Posner, B. Z. (2002). The Leadership Challenge (3rd ed.). San Francisco, California: Jossey-Bass, John Wiley and Sons. Lau, Y. W. \& Tong, C. Q. (2008). Are Malaysian Government-Linked Companies (GLCs) Creating Value?. International Applied 
Economics and Management Letters, 1 (1), 9-12.

Levy, P. E., Cober, R. T. \& Miller, T. (2002).The Effect of Transformational and Transactional Leadership Perceptions on FeedbackSeeking Intentions. Journal of Applied Psychology, 32 (8), 1703-1720.

Lytle, A. L., Brett, J. M., Barsness, Z. I., Tinsley, C. H. \&Janssens, M. (1995).A Paradigm for Confirmatory Cross-Cultural Research in Organizational Behavior. Research in Organizational Behavior, 17, 167-214.

MacKinnon, D. P., Lockwood, C. M., Hoffman, J. M., West, S. G. \& Sheets, V. (2002).A Comparison Methods to Test Mediation and Other Intervening Variable Effects. Psychological Methods, 7 (1), 83-104.

Martins, E. C. \& Terblanche, F. (2003).Building Organisational Culture that Stimulates Creativity and Innovation. European Journal of Innovation Management, 6, 64-74.

Moore, L. L. \& Rudd, R. D. (2006). Leadership Styles of Current Extension Leaders. Journal of Agricultural Education, 47 (1), 6-16.

Muller, R. \& Turner, J. R. (2007).Matching the Project Manager's Leadership Style to Project Type.International Journal of Project Management, 25(1), 21-32.

Nadler, D. A. \& Nadler, M. B. (1998). Champion of Change: How CEOs and Their Companies Are Mastering the Skills of Radical Change. In Fernandez, S. \& Rainey, H. G. (2006).Managing Successful Organizational Change in the Public Sector. Public Administration Review, 66 (2), 168-176.

Nunnally, J. C. (1978). Psychometric Theory. New York, NY: McGraw-Hill.

Ott, J. S. \& Sullivan, D. (1989). Leadership. In Mehra, A., Dixon, A. L., Brass, D. J. \& Robertson, B. (2006). The Social Network Ties of Group Leaders: Implication for Group Performance and Leader Reputation. Organization Science, 17 (1), 64-79.

Parry, K. W. \& Proctor-Thomson, S. (2003). Leadership, Culture and Performance: The Case of the New Zealand Public Sector. Journal of Change Management, 3 (4), 376-399.

Rad, A. M. M. \& Yarmohammadian, M. H. (2006). A Study of Relationship Between Managers' Leadership Style and Employees' Job Satisfaction. Leadership in Health Services, 19 (2), 11-28.

Rossi, P. H. \& Freeman, H. E. (1993). Evaluation: A Systematic Approach (5thed.).Newbury Park, CA: Sage.

Sadri, G. \& Lees, B. (2001). Developing Corporate Culture as A Competitive Advantage. Journal of Management Development, 20 (10), 853-859.

Saleh, A. S., Caputi, P. \& Harvie, C. (2008). Perceptions of Business Challenges Facing Malaysian SMEs: Some Preliminary Results. In M. Obayashi \& N. Oguchi (Eds.), 5th SMEs in a Global Economy conference 2008 (pp. 79-106). Tokyo, Japan: Senshu University.

Sarros, J. C. \& Santora, J. C. (2001).The Transformational-Transactional Leadership Model in Practice.Leadership and Organization Development Journal, 22 (8), 383-394.

Schein, E. H. (1990). Organizational Culture. American Psychologist, 45 (2), 109-119.

Schein, E. H. (1992). Organizational Culture and Ledership (2nd ed.). In Buch, K. \& Wetzel, D. K. (2001). Analyzing and Realigning Organizational Culture. Leadership and Organization Development Journal, 22 (1), 40-44.

Schein, E. H. (1992). Organizational Culture and Leadership (2nd ed.). San Francisco, CA: Jossey Bass.

Schein, E. H. (1996). Culture: The Missing Concept in Organization Studies. Administrative Science Quarterly, 41 (2), $229-240$.

Sekaran, U. (2000). Research Methods for Business: A Skill Building Approach (3rd ed.). Wiley, New York, NY.

Sekaran, U., \& Bougie, R. (2010). Research Methods for Business: A Skill Building Approach (5th ed.). John Wiley and Sons Inc.

SMIDEC (2005). SMI Development Plan (2001-2005). Percetakan Nasional Malaysia Berhad, Kuala Lumpur. "SME Performance 2003" Report, Kuala Lumpur, Malaysia.

Smith, T. \& Reece, J. (1999). The Relationship of Strategy, Fit, Productivity and Business Performance in a Services Setting. Journal of Operations Management, 17 (2), 145-161.

Turner, J. R. \& Muller, R. (2005). The Project Manager's Leadership Style as a Success Factor on Projects: A Literature Review. Project Management Journal, 36 (1), 49-61.

Van Den Berg, P. T. \& Wilderom, C. P. M. (2004). Defining, Measuring, and Comparing Organisational Cultures. Applied Psychology, 53 (4), 570-582.

Visweswaran, C. \& Ones, D. S. (2000). Perspectives on Models of Job Performance. International Journal of Selection and Assessment, $8(4), 216-226$.

Werner, J. M. (2000). Implications of OCB and Contextual Performance for Human Resource Management, Human Resource Management Review, 10 (1), 3-24.

Werner, J. M. \& DeSimone (2009). Human Resource Development (5th ed.). Mason, OH: South-Western Cengage.

Xenikou, A. \& Simosi, M. (2006).Organizational Culture and Transformational Leadership as Predictors of Business Unit Performance. Journal of Managerial Psychology, 21 (6), 566-579. 